Original Research Paper

\title{
Having More Plants at Home During the Covid-19 Pandemic: Is It Just Following A Trend?
}

\author{
Whisnu Febry Afrianto ${ }^{1 *} \&$ Rindang Diannita ${ }^{2}$ \\ ${ }^{1}$ Ecosystem and Biodiversity Indonesia (Ecosbio), Datengan, Grogol, Kediri, Indonesia \\ ${ }^{2}$ Occupational Safety and Health Department, Faculty of Health Science, Universitas Darussalam \\ Gontor, Ponorogo, East Java, Indonesia
}

\author{
Article History \\ Received : December $17^{\text {th }}, 2021$ \\ Revised : December 29 th 2021 \\ Accepted : January $10^{\text {th }}, 2022$ \\ Published : January $20^{\text {th }}, 2022$ \\ *Corresponding Author: \\ Whisnu Febry Afrianto, \\ Ecosystem and Biodiversity \\ Indonesia (Ecosbio), Datengan, \\ Grogol, Kediri, Indonesia \\ Email: \\ whisnu.afrianto@apps.ipb.ac.id
}

\begin{abstract}
The Covid-19 pandemic has drastically changed the social and environmental conditions. People should stay at home for self-isolation and social distancing to avoid the spread of Covid-19. People tend to have more plants at home associated with psychological impact during self-isolation. This study aimed to describe having more plants during the Covid-19 pandemic in Indonesia. A nationwide cross-sectional survey involving an online survey was carried out of an Indonesian population-based sample of 412 respondents from 26 provinces, considered demographic, social, and behavioral variables. The variable affecting the having plants during the Covid-19 pandemic was analyzed using non-parametric analysis of the Kruskal Wallis test. The result showed that people preferred having more plants during the Covid-19 pandemic to reduce negative emotions and feelings. The majority of the respondents tend to have 1-10 plants and spend around $<100 \mathrm{~K}$ (IDR) monthly to maintain and buy plants. They think that efforts to maintain were the most challenging in gardening activities. The majority of the respondents had potted plants at home to make their homes greener. The Kruskal Wallis test showed the $p$-value $(>0.05)$ for all characteristic respondents. Thus, it can be concluded that there was no significant difference regarding the motivation to have planted during the Covid-19 pandemic from characteristic respondents.
\end{abstract}

Keywords: Greening, potted plants, psychological impact, the Covid-19 pandemic

\section{Introduction}

This epidemic Covid-19 occurs in all countries in the world. Based on the World Health Organization (WHO) data about the outbreak of the Covid-19 disease, there were $242,764,798$ coronavirus cases and 4,936,849 deaths as of October 21, 2021 (WHO 2021). Furthermore, Indonesia ranks 14 with $4,237,201$ total cases and 143,077 deaths (Worldometer, 2021). The Covid-19 pandemic has drastically changed the social and environmental conditions. The Covid-19 pandemic has been going on for more than a year, and people face difficult times with uncertainty about when the Covid-19 pandemic will end. The outbreak of Covid-19 negatively impacts people's physiological health and behavior (Yamada et al. 2020; Serafini et al.
2020; Pedrosa et al. 2020). The adverse effects of self-isolation, social distancing, and stressors during the Covid-19 pandemic are boredom, fear, financial loss, and long-lasting psychological effects, such as confusion, posttraumatic stress symptoms, panic disorders, anger depression, and anxiety (Brooks et al. 2020). According to Rajkumar (2020), during the Covid-19 pandemic, people have reported having symptoms of self-reported stress of $8 \%$, anxiety and depression 16-28\%, and sleep disturbance. The COVID-19 pandemic has widely increased the workload for Health Care Workers (HCW), which could cause the impacts on the quality of services and productivity (Arifah et al. 2021). The health risks are unpredictable (Diannita et al. 2020).

In Indonesia, during the Covid-19 pandemic, people's interest in green living 
increases 40 percent from normal conditions, especially for traders of ornamental plants (Litbang Pertanian, 2020; Bukhorida et al. 2021; Putri et al. 2020). This increase is influenced by the lifestyle of the people who have more time at home, so they have more free time to arrange plants in the yard. According to Novriyanti et al. (2021), people start gardening during the Covid-19 pandemic, where $70 \%$ of the total plant growth in the backyard are ornamental plants.

Having plants at home is correlated with more positive emotions during the Covid-19 pandemic (Perez-Urrestarazu et al. 2020). Planting plants in pots can also reduce the adverse effects of the Covid-19 pandemic, namely anger, anxiety, irritability, fear, irritability, and sleep disturbance (Spano et al. 2021; Theodorou et al. 2021). Several studies also reported that individuals had been increasingly engaging in nature activities (Ugolini et al. 2020; Geng et al. 2021; Robinson et al. 2021). On the other hand, no study in Indonesia investigates the relationship between having more plants and mental health issues during the Covid-19 pandemic in Indonesia. Based on the description above, an analysis related to mental health during the Covid-19 pandemic is needed. This study aimed to describe having more plants during the Covid-19 pandemic in Indonesia. Bringing a close relationship between people and nature will increase the motivation to conserve biodiversity (Afrianto and Najah 2017; Afrianto et al. 2020).

\section{Materials and Methods}

\section{Procedures}

The questionnaire was designed anonymously and distributed by using Google Form. The questionnaire consisted of 23 questions divided into four sections, including general information, house profiles, attitudes towards gardening, and emotional states. The questions were the closed-form type and written in a multiple-choice format. The questionnaires were distributed through social networks, such as WhatsApp, Twitter, Linkedin, and Facebook. However, this study did not permit the management of the characteristics of the potential respondents. It allowed a collection of a more significant sample within the tight time limits of the confinement time. The questionnaire was distributed from December 20, 2020, to March 20, 2021. The respondents who answered the questionnaire were dominated from Java Island, i.e., East Java of 82, West Java of 79, Central Java of 65, DKI. Jakarta of 48, D.I. Yogyakarta of 35, and Banten of 22 (Figure 1).

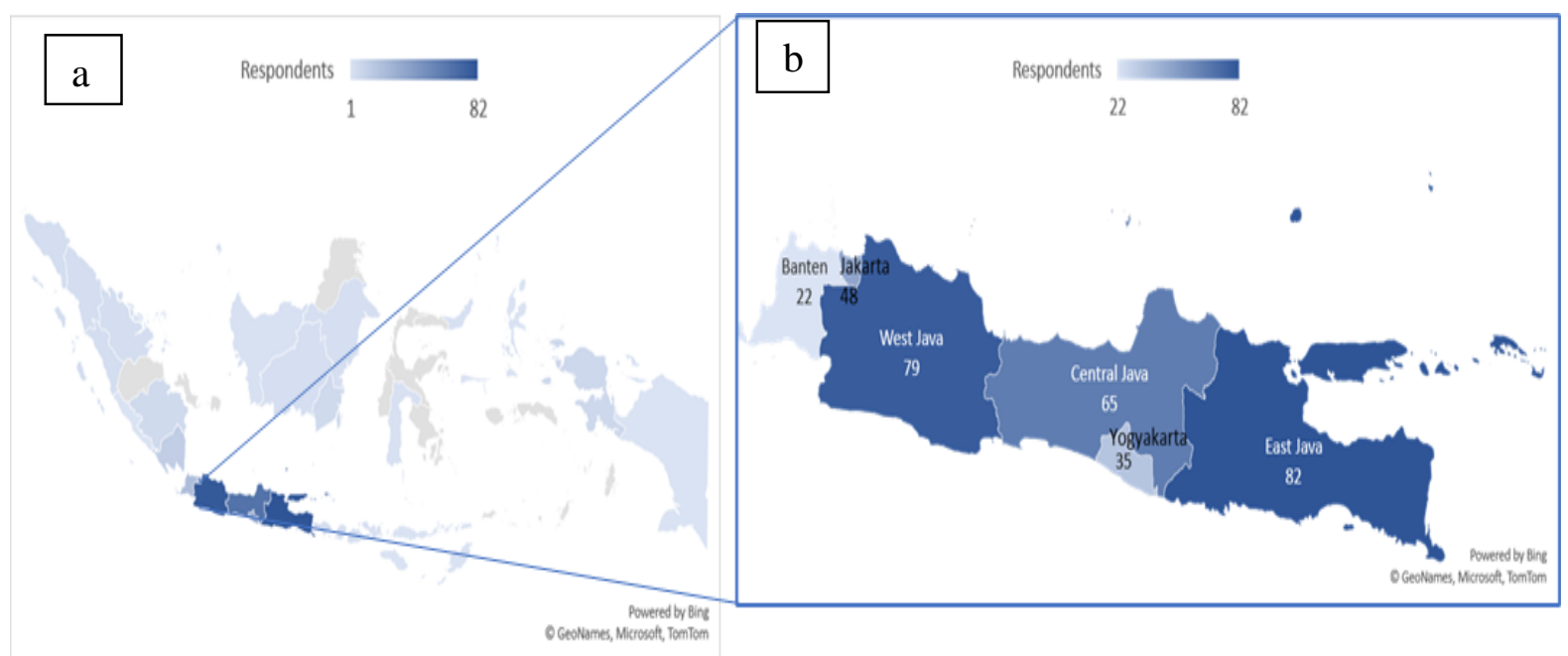

Figure 1. a) Distribution of the collected questionnaire responses based on all the different provinces; b) the most majority of respondents in Java Island; Darker areas represent a higher number of respondents

Data analysis

The total number of respondents was 412 respondents from 26 provinces of 34 provinces in
Indonesia. After the data was validated, ten respondents were eliminated because of uncompleted answers, so there were 402 
respondents. Data processing and statistical analysis were performed using IBM SPSS Statistics 25. Responses for attitude toward nature during the Covid-19 pandemic (Q15-Q18) were ranked as (1) strongly disagree, (2) disagree, (3) undecided, (4) agree, and (5) strongly agree. After that, the variables affecting the having plants during the Covid-19 pandemic were analyzed using non-parametric analysis of the Kruskal Wallis test.

\section{Results and Discussion}

\section{Respondents Profile}

There were $35.32 \%$ male respondents and $64.68 \%$ female respondents. Most respondents were $26-40$ years $(46.52 \%)$ and $18-25(39.05 \%)$ age ranges. Based on the educational background, respondents had bachelor's degrees $(47.76 \%)$ and senior high school (33.33\%). The occupations of the respondents had more than $10 \%$ that were private/government sector employees (40.55\%), students $(24.12 \%)$, teachers/lecturers (15.17\%), and entrepreneurs (11.44\%). They answered that their income was in the range $<\mathrm{Rp} 1.000 .000,00(30.10 \%)$, > $5,000,000(25.87 \%), 3.000 .001-5,000,000$ $(22.89 \%)$, and $1,000,001-3,000,000(21.14 \%)$ (Table 1).

Table 1. Distribution of the respondents by demographic characteristics

\begin{tabular}{|c|c|c|}
\hline 1) Gender & Frequency & $\%$ \\
\hline Male & 142 & 35.32 \\
\hline Female & 260 & 64.68 \\
\hline Total & 402 & 100 \\
\hline \multicolumn{3}{|l|}{ 2) Age Group } \\
\hline $18-25$ & 157 & 39.05 \\
\hline $26-40$ & 187 & 46.52 \\
\hline $41-65$ & 57 & 14.18 \\
\hline $66-80$ & 1 & 0.25 \\
\hline Total & 402 & 100 \\
\hline \multicolumn{3}{|l|}{ 3) Education } \\
\hline Middle school or lower & 8 & 1.99 \\
\hline High school & 134 & 33.33 \\
\hline Undergraduate & 192 & 47.76 \\
\hline Master & 67 & 16.67 \\
\hline Doctor & 1 & 0.25 \\
\hline Total & 402 & 100 \\
\hline \multicolumn{3}{|c|}{ 4) Household income (IDR) } \\
\hline a. $<1.000 .000,00$ & 121 & 30.10 \\
\hline b. $1,000,001-3,000,000$ & 85 & 21.14 \\
\hline c. $3.000 .001-5,000,000$ & 92 & 22.89 \\
\hline d. $>5,000,000$ & 104 & 25.87 \\
\hline Total & 402 & 100 \\
\hline \multicolumn{3}{|l|}{ 5) Occupation } \\
\hline Teacher/lectures & 61 & 15.17 \\
\hline
\end{tabular}




\begin{tabular}{|c|c|c|}
\hline Private/government sectors employee & 163 & 40.55 \\
\hline Entrepreneur & 46 & 11.44 \\
\hline Housewife & 27 & 6.72 \\
\hline Student & 97 & 24.13 \\
\hline Freelancer & 8 & 1.99 \\
\hline Total & 402 & 100 \\
\hline
\end{tabular}

\section{Households Profile}

During the Covid-19 pandemic, people started to work $(36.82 \%)$ and school $(27.86 \%)$ from home, even though some of them still had to work from the office $(29.85 \%)$ or hybrid from office and home $(5.47 \%)$ (Table 2 ).

Most respondents were currently living in big cities with more than 1,000,0000 inhabitants $(48.51 \%)$ and small cities with less than 1.000 .0000 inhabitants $(30.10 \%)$, while $21.39 \%$ of respondents living in villages/rural areas. Regarding the survey, the majority of respondents were living in standalone's houses $(84.83 \%)$, followed by rent/boarding $(13.43 \%)$ and apartments $(1.74 \%)$. In their house, most respondents were living with 3-4 people $(47.01 \%)$, 5-6 people $(28.36 \%), 1-2$ people $(15.67 \%)$, and $>6$ people $(8.96 \%)$. The respondents described the size of their yards that were medium $(47.26 \%)$, small $(39.30 \%)$, and large $(13.43 \%)$. Respondents also answered that their yard could be used for plantings plants and have enough sunlight $88.56 \%$, while $11.44 \%$ of the respondents answered that they had not had enough space for planting plants and had not enough sunlight. When they were asked about Covid-19 experiences, only $6.22 \%$ have been impacted Covid-19, while $40.55 \%$ of their families/relatives have been affected by Covid19.

Table 2. Distribution of the respondents by house profiles

\begin{tabular}{|l|cc}
\hline 6) Activity & Frequency & \% \\
\hline Work from Home (WFH) & 148 & 36.82 \\
\hline Work from Office (WFO) & 120 & 29.85 \\
\hline School from Home (SCO) & 112 & 27.86 \\
\hline WFH and WFO & 22 & 5.47 \\
\hline Total & $\mathbf{4 0 2}$ & $\mathbf{1 0 0}$ \\
\hline 7) Settlement & & 21.39 \\
\hline Rural & 86 & 30.10 \\
Small city (<1,000,000 population) & 121 & 48.51 \\
\hline Large city (>1,000,000 population) & 195 & $\mathbf{1 0 0}$ \\
Total & $\mathbf{4 0 2}$ & 84.83 \\
\hline 8) Type of House & & 1.74 \\
\hline Standalone's house & 341 & 13.43 \\
\hline Apartment & 7 & $\mathbf{1 0 0}$ \\
\hline Rent/boarding & 54 & 39.30 \\
\hline Total & $\mathbf{4 0 2}$ & \\
\hline 9) Yard area & & 158 \\
\hline Small & & \\
\hline
\end{tabular}




\begin{tabular}{|c|c|c|}
\hline Medium & 190 & 47.26 \\
\hline Large & 54 & 13.43 \\
\hline Total & 402 & 100 \\
\hline \multicolumn{3}{|l|}{ 10) Family Member } \\
\hline 1-2 people & \multirow{5}{*}{$\begin{array}{c}63 \\
189 \\
114 \\
36 \\
\mathbf{4 0 2}\end{array}$} & 15.67 \\
\hline 3-4 people & & 47.01 \\
\hline 5-6 people & & 28.36 \\
\hline$>6$ people & & 8.96 \\
\hline Total & & 100 \\
\hline \multicolumn{3}{|l|}{ 11) Condition of Yard } \\
\hline \multirow{2}{*}{$\begin{array}{l}\text { It can be used for plantings plant and has enough for sunlight } \\
\text { It cannot be used for plantings plant and has not enough for } \\
\text { sunlight }\end{array}$} & 356 & 88.56 \\
\hline & 46 & 11.44 \\
\hline \multirow{2}{*}{\multicolumn{2}{|c|}{$\begin{array}{l}\text { 12) Have you ever been exposed to/positive for COVID- } \\
\text { 19? }\end{array}$}} & 100 \\
\hline & & \\
\hline Yes & 25 & 6.22 \\
\hline No & 377 & 93.78 \\
\hline Total & 402 & 100 \\
\hline \multicolumn{3}{|l|}{$\begin{array}{l}\text { 13) Have any of your relatives been exposed to/positive } \\
\text { for COVID-19? }\end{array}$} \\
\hline Yes & 163 & 40.55 \\
\hline No & 239 & 59.45 \\
\hline Total & 402 & 100 \\
\hline
\end{tabular}

\section{Attitude and emotional state toward nature during Covid-19}

Before the Covid-19 pandemic, they stated that they visited urban greening (i.e., parks, urban farming, urban forest, and others) with frequency weekly $(34.33 \%)$, monthly (33.58\%), and every day $(12.44 \%)$. In comparison, $19.65 \%$ of the respondents state they never visit the urban green areas (Figure 2).

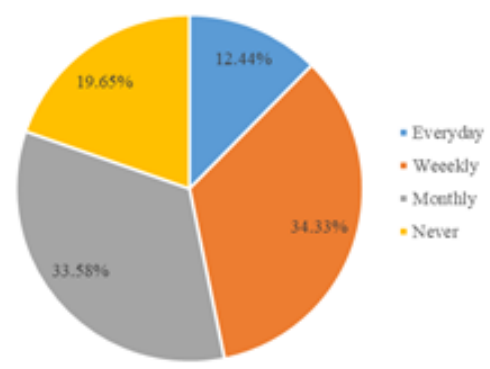

Figure 2. Percentage of the frequency visit to urban greening
This can also be seen from the majority of respondents saying that they strongly agree $(43.78 \%)$ and agree $(42.04 \%)$ that visiting nature is a need for mental health (Q15). In comparison, $2.24 \%$ of the respondents strongly disagree, and $0.5 \%$ strongly disagree. During the Covid-19 pandemic, people have more plants than before (Q16), respondents agreed with $40.52 \%$. It is because they agree $(41,79 \%)$ and strongly agree $(23,38 \%)$ that planting plants is suitable for their mental health (Q17). Moreover, according to the survey, $48,51 \%$ of the respondents agree that planting plants at home gives a positive mood or feeling during the COVID-19 pandemic (Q18) (Figure 3). The non-parametric analysis through the Kruskal Wallis test showed the $p$ value $(>0.05)$ for all characteristic respondents. Thus, it can be concluded that there was no significant difference regarding the motivation to 
have planted during the Covid-19 pandemic from characteristic respondents (Table 3).

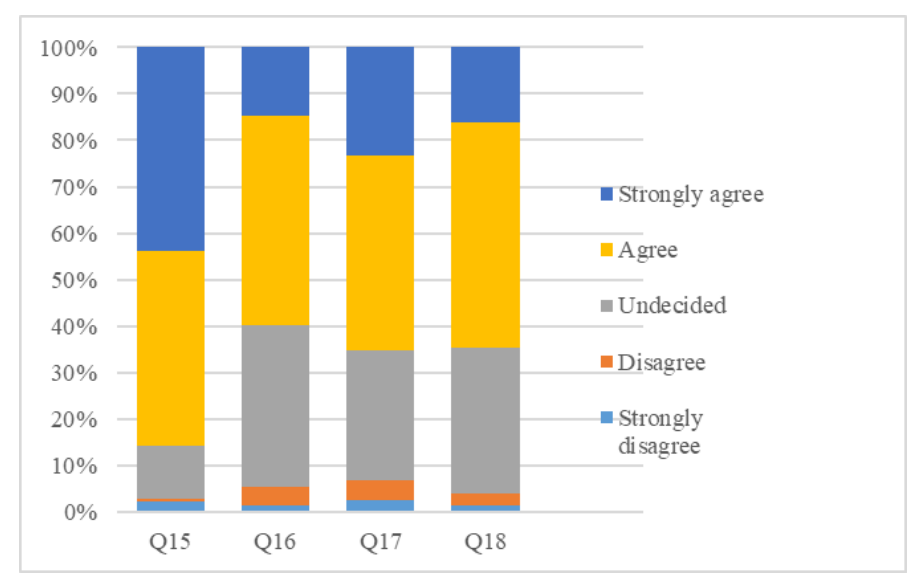

Figure 3. The respondents' response regarding the attitude to greening; Q15: Are urban greening areas (e.g., parks, gardens, yards, forests) necessary for my mental health?; Q16: Would I rather have more plants in my home during the COVID-19 pandemic?; Q17: Having plants at home is good for my mental health?; Q18: Does having plants in your home give a positive mood or feeling during the COVID-19 pandemic?
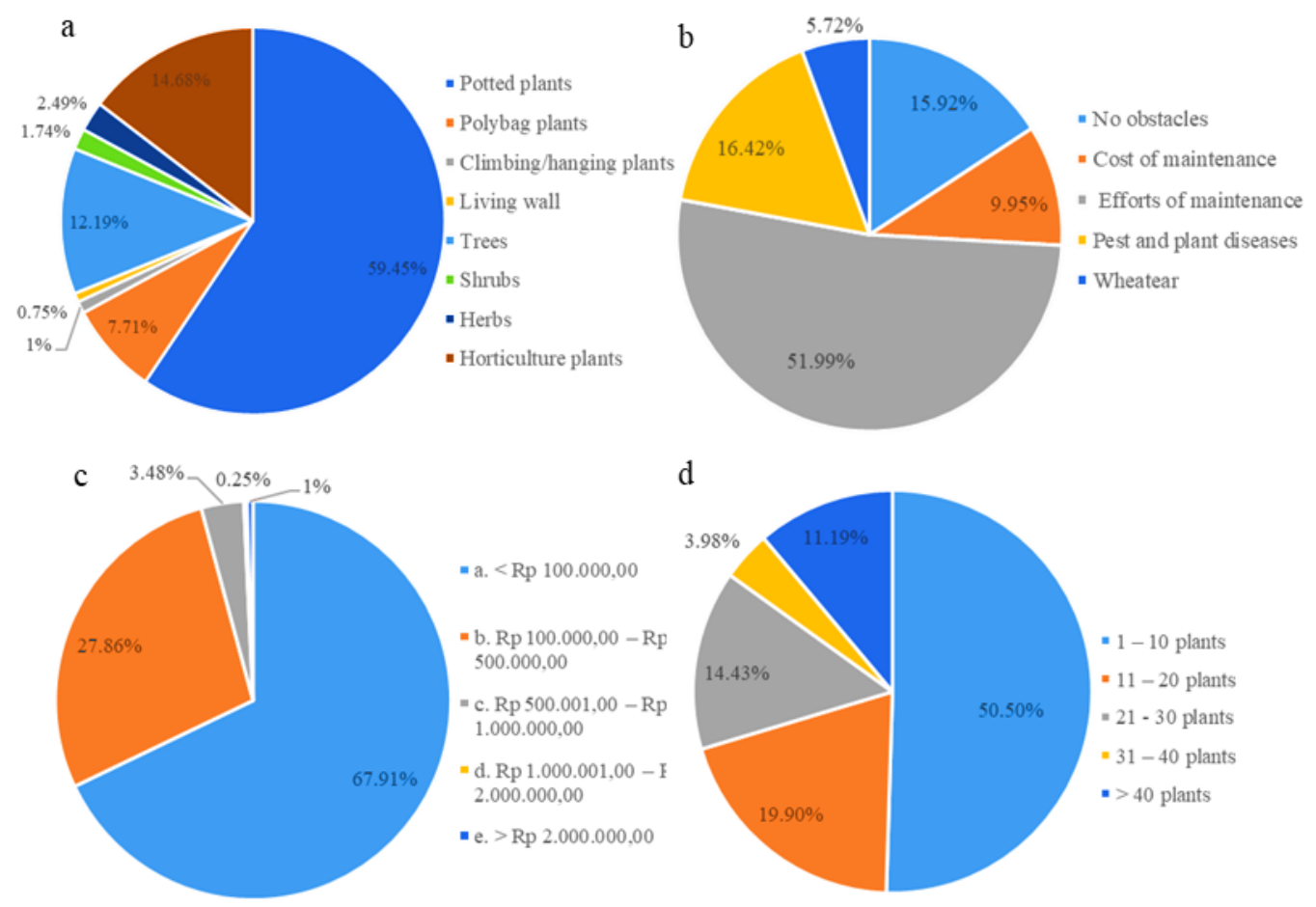

Figure 4. Percentage of the response of the respondent regarding growing plants activities during the Covid-19 pandemic; (a) kind of plants; (b) obstacles of planting plants; (c) monthly budgeting for planting; and (d) number of plants in home

The most popular type of plants growth was potted plants $(59.45 \%)$. Other plants, namely horticulture plants $(14.68 \%)$ and trees $(12.19 \%)$, also had more than $10 \%$. Obstacles faced by respondents were efforts of maintenance
(51.99\%), followed by pest and plant diseases (16.42\%), cost of maintenance (9.95\%), wheatear $(5.72 \%)$, while $15.92 \%$ of the total respondents that they have no obstacles at all $(15.92 \%)$. More than half of the total respondents 
used the monthly budget to buy and maintain plants in the range $<100 \mathrm{~K}$ (IDR) $(67.91 \%)$ for 1 10 plants $(50.50 \%)$ (Figure $4 a-d)$.

The numbers showing how many of the respondents' felt during the Covid-19 pandemic are shown in Figure 5. Among the feelings of the respondents, "calmness" (33.58\%), "stress" $(21.89 \%)$, "fearfulness" (14.93\%), and "optimistic" (14.43\%) come to the fore. "Sadness" (8,71\%), "depression" (5.47\%), and "angriness" $(1.53 \%)$ are the least of the feelings of the respondents.

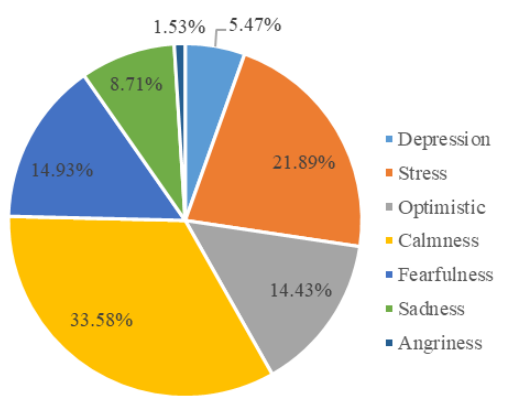

Figure 5. Percentage of positive and negative feelings by respondents during the Covid-19 pandemic

\section{Discussion}

Based on the demography of the respondents were dominated from Java Island. According to the Indonesian Health Ministry (Kemenkes RI), Jakarta has the highest confirmed death cases rate in Indonesia. In that period, Kemenkes RI reported daily confirmed cases of the highest in Jakarta of 4212 patients (7 February 2021) and 66 death cases (16 February 2021) (Kemenkes 2021). Kemenkes RI also reported that most of the symptoms of Covid-19 that were usually conveyed caught fever, weakness, shortness of breath, headache, flu, sore throat, nausea, muscle cramps, chills, stomach pain, and diarrheic.

To avoid the spread of the COVID-19 in Indonesia, the government has made various terms for handling COVID-19. As of April 2020, the government has used at least seven different terms. From the large social activity (PSBB) on April 17, 2020, to the latest implementation of the Implementation of Activity Restrictions Community Activities (PPKM) Java-Bali from July 3, 2021 (Kompas 2021). Thus, people did their activities such as school or work mostly at home (Table 4).

Urban green space areas have several functions for physical, mental health, and wellbeing (Lee and Maheswaran 2011; Afrianto and Tamnge 2015; Lee et al. 2015; Dzhambov et al. 2018; Kondo et al. 2018; Southon et al. 2018; Afrianto et al. 2021). This can also be seen from the majority of respondents saying that they strongly agree $(43.78 \%)$ and agree $(42.04 \%)$ that visiting nature is necessary for mental health. Most of the respondents were young 26-40 years (46.52\%) and 18-25 (39.05\%). According to Roe et al. (2017), coping with stress on low-stress youth is characterized by "finding friends" and "going out". For young age, green space areas can play critical roles in social aspects that make contacts and friends (Seeland et al. 2009). However, mid-age has the perception that urban green space is associated with psychological well-being (Cleary et al. 2019). According to Soga et al. (2020), having a window to see the green view at home improved the wide range of mental health issues during the Covid-19 pandemic. In this study, the respondents also show that they frequently visit at least weekly (34.33\%) or monthly (33.58\%) before the Covid19 pandemic. People who had come to urban green spaces within the past two weeks were associated with higher positive emotions (Hong et al. 2019).

The urban green areas are closed to avoid the spreading of Covid-19. Thus, people start to feel bored and do other positive activities, such as gardening in their homes. It can be seen that the respondents state they agree $(40.52 \%)$ to have more plants in their homes. The most popular type of plants growth was potted plants (59.45\%). According to Fauzi et al. (2021), the factors that influence the purchase decision of ornamental plants are psychological variables, lifestyle, income, and type of work. The demand for several plants, especially potted plants, is increasing up to $85 \%$ (Bukhorida and Febriani 2021). Some of the viral potted plants during the Covid-19 pandemic include Aglaonema, Monstera, Caladium, and others. As a marketing strategy and to make it interested/ear-catching, plant breeders give unique names such as Rabbit Caladium, Rat Caladium, Wayang Caladium, Doraemon Pocket Caladium, and others. On the other hand, respondents also grow horticulture 
plants (14.68\%), trees (12.19\%), and herbs (2.49\%). It can support the Sustainable Food Garden's Government Program (Pekarangan Pangan Lestari/P2L). Planting these various plants can advance food and nutritional security during and after the Covid-19 pandemic (Khan et al. 2020; Lal 2020; Meija et al. 2020; Nicola et al. 2020; Giraud et al. 2021; Mullins et al. 2021).

A lack of agronomical knowledge and effort to maintain was the main obstacle to having plants at home. For example, when pests and plant diseases attack their plants, respondents do not understand handling them. People tended to have only 1-10 plants and spent the lowest budget around $<100$ (IDR). The online webinar increases significantly on several platforms during the Covid-19 pandemic, such as Instagram, Facebook, Zoom, Google Meeting, and Youtube (Reis et al. 2020). The agriculture topic has also been taking place with courses intended for the general audience. Thus, technology can solve their obstacles in growing plants. According to Sofo and Sofo (2020), having a plant can be personal satisfaction and save money in the medium term.

Respondents agree $(41,79 \%)$ and strongly agree $(23,38 \%)$ that having more plants can improve their mental health outcome, and also $48,51 \%$ of the respondents had a more positive feeling by having more plants in their home. Lades et al. (2020) argued that gardening is one the most effective activities to decrease the negative emotions during self-isolation and physical distancing. Similar to that, Amborose et al. (2020) stated that people who do gardening activities expressed high emotional well-being, similar to other activities, such as biking and walking. Having plants indoors can also purify the air condition that impacts an increase in better feeling (Erzsebet et al. 2013; Han and Ruan 2019). People can feel less anxious and nervous with indoor plants and greenery conditions (Chang and Chen 2005). The percentage of respondents who were students was $24.13 \%$. According to Dzhambov et al. (2020), students exposed to greenery have better mental health conditions during their stay at home.

In this study, the highest percentage of positive emotion was "calmness" (33.58\%), and the negative sentiment was "stress" $(21.89 \%)$. People live in rural areas expressed lower negative feelings (Perez-Urrestarazua et al. 2021). It is because they are exposed to a greener landscape than urban people. However, in this study, most of the respondents live in urban areas, and they feel calm because they think the spread is still under control as long as they follow health protocol for Covid-19.

Table 4. Government Regulation to handle Covid-19 by Activity Restrictions (Kompas 2021)

\begin{tabular}{|c|c|c|c|}
\hline No & $\begin{array}{c}\text { Regulation } \\
\text { term }\end{array}$ & Valid date & Description \\
\hline 1 & $\begin{array}{l}\text { Large-Scale } \\
\text { Social } \\
\text { Restrictions } \\
\text { (PSBB) } \\
\text { Transitional } \\
\text { Large-Scale } \\
\text { Social } \\
\end{array}$ & $\begin{array}{l}\text { April to } \\
\text { June } 2020\end{array}$ & $\begin{array}{l}\text { In the policy mechanism, governors/regents/mayors enforce PSBB } \\
\text { including school and workplace from home, restrictions on religious } \\
\text { activities, restrictions on activities in public places or facilities, } \\
\text { restrictions on social and cultural activities, restrictions on } \\
\text { transportation modes, and restrictions on other activities related } \\
\text { explicitly to defense and security aspects. Only essential sectors were } \\
\text { allowed to be fully operational. }\end{array}$ \\
\hline \multirow[t]{3}{*}{2} & $\begin{array}{l}\text { Transitional } \\
\text { Large-Scale } \\
\text { Social } \\
\text { Restrictions }\end{array}$ & $\begin{array}{l}\text { June to } \\
\text { September } \\
2020 .\end{array}$ & $\begin{array}{l}\text { Initially, all works had to be done from home and allowed the office } \\
\text { to work from an office (WFO) up to } 50 \% \text { capacity, transportation } \\
\text { capacity } 50 \text { percent, restaurants were allowed to dine-in up to certain } \\
\text { hours. }\end{array}$ \\
\hline & & $\begin{array}{l}\text { September } \\
\text { to October }\end{array}$ & $\begin{array}{l}\text { The rules were the same, but the name was changed to be Strict Large- } \\
\text { Scale Social Restrictions. }\end{array}$ \\
\hline & & $\begin{array}{l}\text { October } \\
2020 \text { to } \\
\text { January } \\
2021 .\end{array}$ & $\begin{array}{l}\text { The rules were the same, but the name was changed to be Transitional } \\
\text { Large-Scale Social Restrictions } 2 \text {. }\end{array}$ \\
\hline
\end{tabular}




\begin{tabular}{|c|c|c|c|}
\hline No & $\begin{array}{c}\text { Regulation } \\
\text { term }\end{array}$ & Valid date & Description \\
\hline 3 & $\begin{array}{l}\text { Implementatio } \\
\mathrm{n} \text { of Activity } \\
\text { Restrictions } \\
\text { (PPKM) in } \\
\text { Java-Bali }\end{array}$ & $\begin{array}{l}\text { January } 11 \\
2021 \text { for } \\
\text { three weeks }\end{array}$ & $\begin{array}{l}\text { In practice, working in the office can be implemented by } 75 \text { percent } \\
\text { with strict protocols. Teaching and learning activities were carried out } \\
\text { continuously online. Places of worship may be opened with a } \\
\text { maximum capacity of } 50 \text { percent, as well as essential sectors can } \\
\text { operate } 100 \text { percent with restrictions on working hours and visitor } \\
\text { capacity. Meanwhile, restaurants can only accept } 25 \text { percent of } \\
\text { visitors to eat/drink on the spot. Shopping centers were limited to open } \\
\text { until } 19.00 \text {. }\end{array}$ \\
\hline
\end{tabular}

\begin{tabular}{|c|c|c|c|}
\hline 4 & $\begin{array}{l}\text { Micro } \\
\text { Implementatio } \\
\text { n of Activity } \\
\text { Restrictions } \\
\text { (PPKM Micro) } \\
\text { in Java-Bali }\end{array}$ & $\begin{array}{l}\text { February } 9, \\
2021\end{array}$ & $\begin{array}{l}\text { This PPKM micro used strategy community-based to the smallest unit } \\
\text { at the RT/RW level. }\end{array}$ \\
\hline 5 & $\begin{array}{l}\text { Thickening of } \\
\text { Micro PPKM }\end{array}$ & $\begin{array}{l}\text { June } 22, \\
2021, \text { for } \\
\text { two weeks }\end{array}$ & $\begin{array}{l}\text { This thickened micro PPKM policy involved environmental } \\
\text { administrators, village heads, village heads, non-commissioned } \\
\text { officers for village development, and Bhayangkara, the Community } \\
\text { Security and Order supervisor. Tightening was carried out to the } \\
\text { smallest unit, namely RT/RW. For example, at the neighborhood } \\
\text { level, insulation will be carried out if more than five houses whose } \\
\text { residents were affected by Covid-19. }\end{array}$ \\
\hline 6 & $\begin{array}{l}\text { PPKM } \\
\text { Emergency }\end{array}$ & $\begin{array}{l}3 \text { July to } 20 \\
\text { July, } 2021\end{array}$ & $\begin{array}{l}\text { The non-essential sector implementation activities were } 100 \% \text { work } \\
\text { from home (WFH). Teaching and learning activities were carried out } \\
\text { online } 100 \% \text {. Supermarkets, traditional markets, grocery stores can } \\
\text { open maximum until } 20.00 \text { and the maximum capacity of } 50 \% \text {. } \\
\text { Pharmacies/drug shops can be fully opened } 24 \text { hours. Shopping } \\
\text { centers/malls/trade centers were closed. Worship places, public } \\
\text { facilities, facilities for arts, cultural activities, sports, and social } \\
\text { activities were restricted. Restaurants/food stalls could only deliver/ } \\
\text { take away and did not accept eating on the spot. The maximum was } \\
70 \% \text { capacity public transportation with strict procedures }\end{array}$ \\
\hline 7 & $\begin{array}{l}\text { PPKM Level } 3 \\
\text { and } 4\end{array}$ & $\begin{array}{l}\text { August } 30 \\
2021\end{array}$ & $\begin{array}{l}\text { Level 4: Teaching and learning activities were carried out through } \\
\text { distance learning. For eating/drinking activities in food stalls, street } \\
\text { vendors, snack stalls were allowed to open with health protocols until } \\
20.00 \text { local time with a maximum of } 3 \text { visitors eating at the place and } \\
\text { a maximum meal time of } 30 \text { minutes. Tourist attractions were } \\
\text { temporarily closed. Art, culture, sports, and social activities with } \\
\text { PPKM Level } 4 \text { were temporarily closed. For public transportation, a } \\
\text { maximum regulation of } 50 \text { percent of capacity was applied. Wedding } \\
\text { receptions were abolished. }\end{array}$ \\
\hline & & & $\begin{array}{l}\text { Level 3: At PPKM Level 3, teaching and learning can be done through } \\
\text { limited face-to-face and or distance learning. As for PPKM Level 3, } \\
\text { the eating/drinking activities were allowed to open with health } \\
\text { protocols until } 21.00 \text { local time, with a maximum of } 50 \text { percent of } \\
\text { visitors eating at capacity. While for a maximum meal time of } 60 \\
\text { minutes. The dining time limit is open until } 21.00 \text { local time. The } \\
\text { table capacity is two people, and the whole mealtime is } 60 \text { minutes. } \\
\text { The maximum capacity setting is } 70 \text { percent. }\end{array}$ \\
\hline
\end{tabular}




\section{Conclusion}

In conclusion, during the Covid-19 pandemic, most respondents intended to have more plants because they should self-isolation and social distance. They think that it can provide a more positive mood and feeling. Most of the respondent's state that they preferred to have potted plants, horticulture, and trees with an average of 1-10 plants at home. They spent monthly budgeting on buying and maintaining $<100 \mathrm{~K}$ (IDR), and half of the total respondents feel that maintaining is the obstacle in gardening. In this study, the highest percentage of positive emotion was "calmness" and the negative sentiment was "stress".

\section{Acknowledgment}

We thank all respondents who completed our survey.

\section{Reference}

Afrianto, W.F., \& Tamnge, F. (2015). Conceptual foundation to develop ecosmart city in Indonesia. In: Fernadez JC, Wulandari D, Damayanti EK (eds). Proceedings of SEAMEO BIOTROP Second International Conference on Tropical Biology: "Ecological Restoration in Southeast Asia: Challenges, Gains, and Future Directions". SEAMEO BIOTROP, Bogor, 12-13 October 2015.

Afrianto, W. F., \& Najah, S. K. (2017). Peran Citizen Science dalam Upaya konservasi Biodiversitas. Prosiding Semnas Biodiversitas, 6(1), 162-164.

Afrianto, W. F., Tamnge, F., \& Hasanah, L. N. (2020). A relation between ethnobotany and bioprospecting of edible flower Butterfly Pea (Clitoria ternatea) in Indonesia. Asian Journal of Ethnobiology, 3(2): 51-61.

Afrianto, W.F., Wati, S.I., \& Hidayatullah, T. (2021). The suitability assessment of the tree species in the urban parks and urban forest in Kediri City, East Java, Indonesia. Nusantara Bioscience 13(2): 131-139.

Ambrose, G., Das, K., Fan, Y., \& Ramaswami, A. (2020). Is gardening associated with greater happiness of urban residents? A multi-activity, dynamic assessment in the Twin-Cities region, USA. Landscape and Urban Planning 198: 103776.

Brooks, S.K., Webster, R.K., Smith, L.E., Woodland, L., Wessely. S., Greenberg, N., \& Rubin, G.J. (2020). The psychological impact of quarantine and how to reduce it: rapid review of the evidence. The Lancet 395(10227): 912-920.

Bukhorida, F.F., \& Febriani, D.P. (2021), September). Pengaruh covid-19 terhadap kenaikan penjualan tanaman hias kios rachel di desa rembang, kabupaten kediri. In Seminar Nasional Manajemen, Ekonomi dan Akuntansi.

Chang CY, \& Chen PK. (2005). Human response to window views and indoor plants in the workplace. HortScience 40(5): 13541359.

Cleary, A., Roiko, A., Burton, N.W., Fielding, K.S., Murray, Z., \& Turrell, G. (2019). Changes in perceptions of urban green space are related to changes in psychological well-being: Cross-sectional and longitudinal study of mid-aged urban residents. Health \& place 59: 102201

Diannita, R., Indasah., \& Siyoto S. (2020). Analysis of Work Accidents Based on K3 Knowledge and Work Behavior at Muhammadiyah Hospital in Ponorogo. Journal for Quality in Public Health 3(2): 383-389.

Dzhambov, A.M., Lercher, P., Browning, M.H.E.M., Stoyanov, D., Petrova, N., Novakov, S., \& Dimitrova, D.D. (2020). Does greenery experienced indoors and outdoors provide an escape and support mental health during the COVID-19 quarantine? Environmental Research: 110420.

Dzhambov, A. M., Markevych, I., Hartig, T., Tilov, B., Arabadzhiev, Z., Stoyanov, D, Gatseva P, \&Dimitrova, D. D. (2018). Multiple pathways link urban green-and bluespace to mental health in young adults. Environmental research, 166, 223-233.

Erzsebet, B.U.T.A., Cantor, M., Singureanu, V., Husti, A., Denisa, H.O.R.A., \& Mihai, B.U.T.A. (2013). Ornamental plants used for improvement of living, working and studying spaces microclimate. ProEnvironment Promediu, 6(16):562- 
565.

Fauzi, M.H., Susilowati, D., \& Machfudz, M. (2021). Analysis of Factors Influencing Decisions to Purchase Ornamental Plants During the Covid-19 Pandemic In Bumiaji District, Batu City. Jurnal Sosial Ekonomi Pertanian dan Agribisnis 9(3). [Indonesian]

Geng, D. C., Innes, J., Wu, W., \& Wang, G. (2021). Impacts of COVID-19 pandemic on urban park visitation: a global analysis. Journal of forestry research, 32(2), 553567.

Giraud, E.G., El-Sayed, S., \& Opejin, A. (2021). Gardening for Food Well-Being in the COVID-19 Era. Sustainability 13(17): 119.

Han, K.T., \& Ruan, L.W. (2019). Effects of indoor plants on self-reported perceptions: a systemic review. Sustainability 11(16): $1-26$.

Hong, S.K., Lee SW, Jo, H.K., \& Yoo, M. (2019). Impact of frequency of visits and time spent in urban green space on subjective well-being. Sustainability, 11(15): 1-25.

Kemenkes (2021). Latest Official Information Media of Emerging Infectious Diseases.https://covid19.kemkes.go.id/

Khan, M.M., Akram, M.T., Janke, R., \& Qadri, R.W.K, Al-Sadi AM, Farooque AA. (2020). Urban horticulture for food secure cities through and beyond COVID-19. Sustainability, 12(22): 1-21.

Kompas (2021). Change the Term PSBB, Micro PPKM, Emergency, Up to Level 4, What's the Difference? https://www.kompas.com/tren/read/2021/ 07/23/113000465/gonta-ganti-istilahpsbb-ppkm-mikro-darurat-hingga-level-4apa-bedanya-

Kondo, M.C., Fluehr, J.M., McKeon, T., \& Branas, C.C. (2018). Urban green space and its impact on human health. International Journal of Environmental Research and Public Health 15(3): 445

Lades, L.K., Laffan, K., Daly, M., \& Delaney, L. (2020). Daily emotional well - being during the COVID - 19 pandemic. British journal of health psychology 25(4): 902911.

Lal, R. (2020). Home gardening and urban agriculture for advancing food and nutritional security in response to the COVID-19 pandemic. Food security: 1-6.

Lee, A.C.K., Jordan, H.C., \& Horsley, J. (2015). Value of urban green spaces in promoting healthy living and wellbeing: prospects for planning. Risk Management and Healthcare Policy 8: 131: 137.

Lee, A.C., \& Maheswaran, R. (2011). The health benefits of urban green spaces: a review of the evidence. Journal of Public Health 33(2): 212-222.

Mejia, A., Bhattacharya, M., Nigon-Crowley, A., Kirkpatrick K, \& Katoch C. (2020). Community gardening during times of crisis. Journal of Agriculture, Food Systems, and Community Development 10(1): 1-7.

Mullins, L., Charlebois, S., Finch, E., \& Music, J. (2021). Home food gardening in Canada in response to the COVID-19 Pandemic. Sustainability, 13(6): 1-12.

Nicola, S., Ferrante, A., Cocetta, G., Bulgari, R., Nicoletto, C., Sambo, P., \& Ertani, A. (2020). Food supply and urban gardening in the time of Covid-19. BulletinUASVM Horticulture 77(2):141-144.

Novriyanti, N., Iswandaru, D., \& Damayanti, I. (2021). The behavior of urban communities in planting useful plants in the yard during covid-19 pandemic. Media Konservasi 26(1): 9-16.

Pedrosa, A.L., Bitencourt, L., Fróes, A.C.F., Cazumbá, M.L.B., Campos, R.G.B., de Brito, S.B.C.S., \& e Silva, A.C.S. (2020). Emotional, behavioral, and psychological impact of the COVID-19 pandemic. Frontiers in Psychology 11: 1-18.

Pérez-Urrestarazu, L., Kaltsidi, M.P., Nektarios, P.A., Markakis, G., Loges, V., Perini, K., \& Fernández-Cañero, R. (2021). Particularities of having plants at home during the confinement due to the COVID19 pandemic. Urban Forestry \& Urban Greening 59: 126919.

Putri, F.A., Putri, S.S., Yulianti, R., \& Sifa, S.I. (2021). Prediction of Ornamental Plant's Sales from Monte-Carlo Simulations. Khazanah: Jurnal Mahasiswa, 12(2).

Rajkumar, R.P. (2020). COVID-19 and mental health: A review of the existing literature. Asian journal of psychiatry 52: 102066. 
Reis, S.N., Reis, M.V.D., \& Nascimento, Â.M.P.D. (2020). Pandemic, social isolation and the importance of peopleplant interaction. Ornamental horticulture 26: 399-412.

Robinson, J. M., Brindley, P., Cameron, R., MacCarthy, D., \& Jorgensen, A. (2021). Nature's role in supporting health during the COVID-19 pandemic: A geospatial and socioecological study. International journal of environmental research and public health, 18(5), 2227.

Roe, J.J., Aspinall, P.A., \& Ward, T.C. (2017). Coping with stress in deprived urban neighborhoods: what is the role of green space according to life stage?. Frontiers in Psychology 8: 1-17.

Seeland, K., Dübendorfer, S., \& Hansmann, R. (2009). Making friends in Zurich's urban forests and parks: The role of public green space for social inclusion of youths from different cultures. Forest Policy and economics 11(1): 10-17.

Serafini, G., Parmigiani, B., Amerio, A., Aguglia, A., Sher, L., \& Amore, M. (2020). The psychological impact of COVID-19 on the mental health in the general population. QJM: An International Journal of Medicine, 113(8), 531-537.

Sofo, A., \& Sofo, A. (2020). Converting home spaces into food gardens at the time of Covid-19 quarantine: All the benefits of plants in this difficult and unprecedented period. Human Ecology 48(2): 131-139.

Soga, M., Evans, M.J., Tsuchiya, K., \& Fukano, Y. (2020). A room with a green view: the importance of nearby nature for mental health during the COVID - 19 pandemic. Ecological Applications: 1-10.

Southon, G.E., Jorgensen, A., Dunnett, N., Hoyle, H., \& Evans, K.L. (2018). Perceived species-richness in urban green spaces: Cues, accuracy and well-being impacts. Landscape and Urban Planning 172: 1-10.

Spano, G., D’Este, M., Giannico, V., Elia, M., Cassibba, R., Lafortezza, R., \& Sanesi, G. (2021). Association between indooroutdoor green features and psychological health during the COVID-19 lockdown in Italy: A cross-sectional nationwide study. Urban forestry \& urban greening, 62,
127156.

Theodorou, A., Panno, A., Carrus, G., Carbone, G. A., Massullo, C., \& Imperatori, C. (2021). Stay home, stay safe, stay green: The role of gardening activities on mental health during the Covid-19 home confinement. Urban Forestry \& Urban Greening 61: 127091.

Ugolini, F., Massetti, L., Calaza-Martínez, P., Cariñanos, P., Dobbs, C., Ostoić, S. K., Marin, A.M., Pearlmutter, D., Saaroni, H., Sauliene, I., Simoneti, M., Verlic, A., Vuletic, D., ... \& Sanesi, G. (2020). Effects of the COVID-19 pandemic on the use and perceptions of urban green space: An international exploratory study. Urban forestry \& urban greening, 56, 126888.

Yamada, Y., Ćepulić, D.B., Coll-Martín, T., Debove, S., Gautreau, G., Han, H., Rasmussen, J., Tran, T.P., \& Travaglino, A., Lieberoth. A. (2021). COVIDiSTRESS Global Survey dataset on psychological and behavioural consequences of the COVID-19 outbreak. Scientific Data 8(1): 1-23.

WHO (2021). WHO Coronavirus (Covid-19) Dashboard. https://covid19.who.int/

Worldmeter (2021). Covid-19 Coronavirus Pandemic.https://www.worldometers.info /coronavirus/ 